\title{
Nitrification and denitrification in Wadden Sea sediments (Königshafen, Island of Sylt, Germany) as measured by nitrogen isotope pairing and isotope dilution
}

\author{
Karen M. Jensen ${ }^{1,2, *}$, Mikael H. Jensen ${ }^{1}$, Erik Kristensen ${ }^{1}$ \\ ${ }^{1}$ Institute of Biology, ${ }^{2}$ Institute of Biochemistry, Odense University, Campusvej 55, DK-5230 Odense M, Denmark
}

\begin{abstract}
Seasonal variation of sediment denitrifıcation and nitrification in darkness was measured by the nitrogen isotope pairing and the nitrate isotope dilution techniques in 3 different sediment types: coarse sand, fine sand and muddy sand ( $S, A$ and $M$, respectively) in intertidal Königshafen, Island of Sylt, Germany. The temporal pattern of denitrification based on nitrate from the overlying water could be explained by variations in the nitrate concentration and oxygen penetration depth in all 3 sediment types. Highest rates ( 8 to $48 \mu \mathrm{mol} \mathrm{m} \mathrm{m}^{-2} \mathrm{~h}^{-1}$ ) were observed in April 1994 when nitrate concentration in the overlying water was 65 to $70 \mu \mathrm{M}$ and the lowest $\left(0.2\right.$ to $\left.1.1 \mu \mathrm{mol} \mathrm{m} \mathrm{m}^{-2} \mathrm{~h}^{-1}\right)$ in summer and fall when nitrate was depleted from the water phase. The annual mean dark denitrification, of which 69 to $75 \%$ was due to overlying water nitrate, increased in the sequence $\mathrm{A}, \mathrm{S}$ and $\mathrm{M}$ in accord with increasing sediment oxygen uptake. All 3 sediments types exhibited low nitrification in early winter. At $S$ and $M$, maximum nitrification was measured in spring and late summer $\left(8\right.$ to 17 and 27 to $28 \mu \mathrm{mol} \mathrm{m} \mathrm{m}^{-2} \mathrm{~h}^{-1}$, respectively\}, whereas nitrification was repressed in mid summer. Maximum dark nitrification here generally occurred at the time of the highest activity of the benthic microalgae (measured as oxygenbased dally gross primary production). At Stn $A_{1}$ maximum nitrification was measured in mid summer $\left(26 \mu \mathrm{mol} \mathrm{m} \mathrm{m}^{-2} \mathrm{~h}^{-1}\right)$, when daily gross primary production was low. The 2 different seasonal patterns of nitrification can be explained by differences in oxygen and ammonium availability. In all sediment types, a low degree of coupling between nitrification and denitrification (in relation to total nitrification) was evident, especially during summer or autumn. Annual mean dark nitrification, of which 11 to $27 \%$ was coupled to denitrification, was higher in the muddy sediment than in the 2 sandy sediments.
\end{abstract}

KEY WORDS: Intertidal · Sediment - Nitrification · Denitrification - Isotope pairing · Isotope dilution

\section{INTRODUCTION}

The increasing eutrophication of coastal areas has long been a matter of concern. However, it is not yet fully clear to what extent coastal marine sediments are capable of removing increased nitrogen loads. It is therefore necessary to obtain a better knowledge of key processes such as benthic nitrification and denitrification and especially the coupling between them, i.e. when the nitrate produced from nitrification is subsequently denitrified. A new tool, the isotope pairing technique, has recently been introduced for measuring

•E-mail:kmj@biochem.ou.dk sediment denitrification (Nielsen 1992). By this technique, total denitrification is separated into denitrification of nitrate originating from the water phase and denitrification coupled to nitrification. The applicability of this technique has been shown in several investigations (e.g. Rysgaard et al. 1993, 1995, RisgaardPetersen et al. 1994, Lohse et al. 1996, Nielsen \& Glud 1996). The more traditional nitrate isotope dilution technique, on the other hand, provides a measure of the part of nitrification where nitrate is released to the overlying water (Koike \& Hattori 1978, Chatarpaul et al. 1980, Nishio et al. 1983). This technique has recently been improved by applying new analytical methods (Risgaard-Petersen et al. 1993, Højberg et al. 
1994, Jensen et al. 1996). The 2 techniques have been successfully combined in studies of nitrification and denitrification under controlled conditions in manipulated sediment systems (Rysgaard et al. 1993, 1994, Risgaard-Petersen et al. 1994, Sloth et al. 1995, Pelegrí \& Blackburn 1995).

The purpose of the present study was to determine seasonal variations of dark nitrification and denitrification in different sediment types of an intertidal area using the isotope pairing and isotope dilution techniques. The temporal and spatial variations in physical and chemical conditions required that the reliability of the techniques was thoroughly verified. The study is part of an integrated investigation of the biogeochemistry of sediments in the Königshafen bay (Island of Sylt, Gormany) in the northern Wadden Sea

\section{MATERIALS AND METHODS}

Study site. The study was carried out in the shallow intertidal embayment Konigshafen on the Island of Sylt, Germany. The bay is sheltered from winds and waves, but strongly influenced by semi-diurnal tides (amplitude $1.7 \mathrm{~m}$; Reise 1985). Three stations in the intertidal zone, S, A and M (Fig. 1), were investigated on 8 occasions from April 1993 to July 1994. The sediment at $\mathrm{S}$ and $\mathrm{A}$ was composed of coarse and fine sand, respectively, whereas $M$ had a higher content of finegrained material (muddy sand). The mean porosity in the upper $10 \mathrm{~cm}$ at $\mathrm{S}$ and $\mathrm{A}$ varied between 0.32 and 0.38 , whereas values between 0.44 and 0.58 were found at $M$; the highest values for all 3 stations were found in the upper 0 to $3 \mathrm{~mm}$. Organic content, determined as loss on ignition (LoI) at $520^{\circ} \mathrm{C}$ according to Kristensen \& Andersen (1987), decreased at S and A from $0.8 \%$ in the upper few millimeters to $0.2-0.4 \%$ at $10 \mathrm{~cm}$ depth. At Stn $M$, the organic content in the
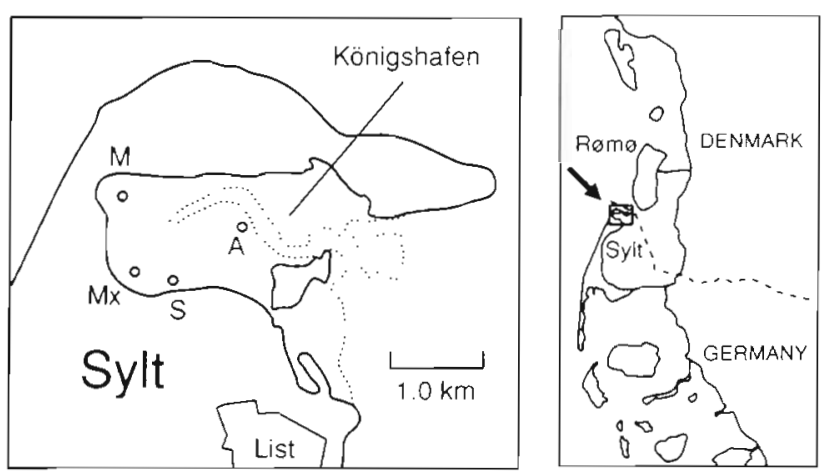

Fig. 1 Study area: Königshafen, Island of Sylt, Germany. Sampling stations situated in the intertidal zone are indicated. Dotted line: mean low water level upper 0 to $3 \mathrm{~mm}$ varied seasonally from $1 \%$ in winter to $6 \%$ in summer. At greater depths, the organic content at this station ranged from 0.5 to $4 \%$ in an irregular pattern. The macrofaund at Stn $\mathrm{M}$ was dominated by Cerastoderma edule $\left(100\right.$ to $\left.300 \mathrm{~m}^{-2}\right)$ and Macoma balthica $\left(40\right.$ to $\left.300 \mathrm{~m}^{-2}\right)$. At $\mathrm{S}$, Hydrobia ulvae occurred in high numbers $\left(4000\right.$ to $>20000 \mathrm{~m}^{-2}$ ) for most of the year along with small specimens of Arenicola marina and various unidentified polychaetes $\left(100\right.$ to $\left.1000 \mathrm{~m}^{-2}\right)$. At Stn A, large specimens of $A$. marina (30 to $70 \mathrm{~m}^{-2}$ ) dominated, whereas H. ulvae was absent. Stn $\mathrm{Mx}$ (Fig. 1), which was used only in preliminary studies, resembled Stn $M$ in many respects. Salinity at all stations ranged between 23 and $33 \%$, lowest during winter and early spring.

Sediment collection and handling. Sediment cores were collected in daylight during water cover. Between 4 and 9 (usually 6 ) intact cores were taken to 9-11 cm depth with $8 \mathrm{~cm}$ (inner diameter) core tubes leaving 9 to $11 \mathrm{~cm}$ overlying water. The cores were brought to a nearby laboratory within 1 to $2 \mathrm{~h}$ and submersed uncapped into a darkened circular tank containing 40 l unfiltered aerated seawater from the location. The tank water was circulated by an Eheim pump and the water overlying the cores was stirred by spinning teflon-coated magnets (60 to $70 \mathrm{rpm}) \mathrm{ca} 6 \mathrm{~cm}$ above the sediment surface. During each study period (1 to $2 \mathrm{wk}$ ), the temperature of flood water at the beginning of the period was used as a standard incubation temperature $\left(4.5\right.$ to $\left.20^{\circ} \mathrm{C}\right)$.

Seasonal ${ }^{15} \mathrm{~N}$-incubations. Denitrification was measured by the isotope pairing method of Nielsen (1992) This technique provides rates of denitrification due to nitrate from the overlying water as well as denitrification coupled to nitrification. Furthermore, by monitoring the isotope dilution of added ${ }^{15} \mathrm{NO}_{3}{ }^{-}$the rate of nitrification not coupled to denitrification can be measured simultaneously (Koike \& Hattori 1978, Nishio et al. 1983)

After $2 \mathrm{~h}$ preincubation in darkness, the overlying water of the sediment cores was enriched with ${ }^{15} \mathrm{NO}_{3}{ }^{-}$ (30 to $60 \mu \mathrm{M}$ ) by addition of a ${ }^{15} \mathrm{NO}_{3}{ }^{-}$stock solution to the tank water followed by vigorous stirring for about $15 \mathrm{~min}$. Initial water samples for analysis of dissolved $\mathrm{O}_{2}$, dissolved inorganic nitrogen (DIN: $\mathrm{NH}_{4}{ }^{+}, \mathrm{NO}_{3}{ }^{-}$, $\mathrm{NO}_{2}{ }^{-}$) and ${ }^{15} \mathrm{~N}$ distribution in dissolved $\mathrm{N}_{2}$ and $\mathrm{NO}_{3}{ }^{-}$ $\left(+\mathrm{NO}_{2}{ }^{-}\right)$were taken before capping the cores (within $0.5 \mathrm{~h}$ after addition of ${ }^{15} \mathrm{NO}_{3}{ }^{-}$). Incubation was done in darkness with stirred water phases for 0.6 to $16 \mathrm{~h}$. depending on season and station. During most incubations, sampling was performed in a time-series to test for linearity of the measured rates. The $\mathrm{O}_{2}$ concentration rarely decreased below $75 \%$ of air saturation at the end of incubation to prevent an influence from diminished $\mathrm{O}_{2}$ penetration on nitrification and denitri- 
fication. The incubation was terminated by uncapping the cores and quickly repeating the water sampling before carefully mixing the sediment and the remaining overlying water into a homogenous slurry. Samples for mass spectrometric determination of ${ }^{15} \mathrm{~N}$ in $\mathrm{N}_{2}$ and $\mathrm{O}_{2}$ content in the slurry were taken after a few minutes of sedimentation; the $\mathrm{O}_{2}$ content was measured in order to check for proper inhibition of denitrification in the slurry prior to sampling and preservation. Finally, the sediment slurry was sieved ( $1 \mathrm{~mm}$ mesh) for quantification of larger macrofauna.

Water samples for dissolved $\mathrm{O}_{2}$ were taken in $25 \mathrm{ml}$ Winkler bottles. Water samples for determination of ${ }^{15} \mathrm{~N}$ in $\mathrm{N}_{2}$ were stored in 8.5 (or 12.5) ml gas-tight containers (Exetainers, Labco, High Wycombe, UK) with screwcap lids (excluding any air bubbles) and preserved with $100 \mu \mathrm{l} 80 \% \mathrm{w} / \mathrm{w} \mathrm{ZnCl}_{2}$ or $10 \mu \mathrm{l} 0.06 \mathrm{M}$ $\mathrm{HgCl}_{2}$. Samples for parallel determination of ${ }^{15} \mathrm{~N}$ in $\mathrm{N}_{2}$ and for $\mathrm{O}_{2}$ content were taken in $8.5 \mathrm{ml}$ Exetainers and preserved with $20 \mu \mathrm{l} 10 \mathrm{M} \mathrm{NaOH}$. The DIN water samples and the samples for ${ }^{15} \mathrm{~N}$ content in $\mathrm{NO}_{3}{ }^{-}$were $\mathrm{GF} / \mathrm{C}$-filtered and stored frozen in $20 \mathrm{ml}$ scintillation vials.

Test incubations. Influence of ${ }^{15} \mathrm{NO}_{3}{ }^{-}$addition: To test for interference of added nitrate on denitrification of ambient nitrate and to assure that an even distribution of nitrate isotopes existed in the denitrification zone (Nielsen 1992), a series of incubations using different additions of ${ }^{15} \mathrm{~N}$-nitrate was performed. In April 1994, when ambient nitrate concentration was high (65 to $71 \mu \mathrm{M}$ ), 9 cores from $S, A$ and $M$ were enriched with 30,60 and $120 \mu \mathrm{M}^{15} \mathrm{NO}_{3}{ }^{-}$in triplicate. In July 1994, when ambient nitrate concentration was low $(<0.1 \mu \mathrm{M}), 7$ concentrations between 5 and $120 \mu \mathrm{M}$ ${ }^{15} \mathrm{NO}_{3}{ }^{-}$were used on 1 core each from $\mathrm{A}$ and $\mathrm{M}$. The incubation temperatures in April and July were approximately 6.5 and $20^{\circ} \mathrm{C}$, respectively.

Microalgal interference: To test for a possible impact of microphytobenthic dark uptake of dissolved inorganic nitrogen on the nitrification/denitrification assay, $500 \mu \mathrm{M} \mathrm{NH}_{4}{ }^{+}$was added to 3 out of 6 cores incubated with $60 \mu \mathrm{M}^{15} \mathrm{~N}$-nitrate, assuming that the microphytobenthos would preferentially assimilate $\mathrm{NH}_{4}{ }^{+}$ (e.g. Nielsen et al. 1990b). The incubations were done on sediment cores which had just previously been used for the measurement of unamended fluxes in a lightdark cycle (E. Kristensen, M. J. Jensen \& K. M. Jensen unpubl.). The cores were preincubated in light for $8 \mathrm{~h}$ and then received the standard $2 \mathrm{~h}$ preincubation in darkness. These ammonium addition (AA) incubations were performed on $S, A$ and $M$ in April 1994. In another series, cores were preincubated for approximately $48 \mathrm{~h}$ in darkness to eliminate (or at least greatly reduce) the microalgal assimilation of inorganic nitrogen before $30 \mu \mathrm{M}{ }^{15} \mathrm{~N}$-nitrate was added. These con- stant-dark (CD) incubations were conducted on $\mathrm{S}$ and Mx in June 1993. Both the AA and the CD incubations were otherwise performed as the standard seasonal ${ }^{15} \mathrm{~N}$-incubations.

Chemical analysis. $\mathrm{O}_{2}$ was analyzed by the standard Winkler technique. DIN samples were analyzed for $\mathrm{NO}_{3}{ }^{-}, \mathrm{NO}_{2}{ }^{-}$and $\mathrm{NH}_{4}{ }^{+}$on an autoanalyzer by standard methods (Armstrong et al. 1967, Solorzano 1969) or for $\mathrm{NH}_{4}{ }^{+}$by a manual salicylate hypochlorite method (Bower \& Holm-Hansen 1980). Since $\mathrm{NO}_{2}{ }^{-}$was always low in concentration, it is included in $\mathrm{NO}_{3}{ }^{-}$The ${ }^{15} \mathrm{~N}$ labelling of dissolved $\mathrm{N}_{2}$ in the $\mathrm{ZnCl}_{2}$ (or $\mathrm{HgCl}_{2}$ ) preserved samples were measured by GC-MS (Sira Series II, VG-Isotech, Middelwich, UK) as described by Rysgaard et al. (1994). The $\mathrm{NaOH}$ preserved samples were analyzed for ${ }^{15} \mathrm{~N}$ labelling and $\mathrm{O}_{2}$ content by membrane inlet-MS as described by Jensen et al. (1996). The samples for ${ }^{15} \mathrm{~N}$ in $\mathrm{NO}_{3}{ }^{-}$were measured by membrane inlet-MS after bacterial reduction of $\mathrm{NO}_{3}{ }^{-}$to $\mathrm{N}_{2}$ (Jensen et al. 1996).

Calculations. The rate of denitrification was calculated according to the procedures and assumptions of Nielsen (1992). The concentration of dissolved $N_{2}$ in air-saturated water was used as an internal standard to obtain the areal production rate of single and double labelled $\mathrm{N}_{2}\left(p^{14} \mathrm{~N}^{15} \mathrm{~N}\right.$ and $\left.p^{15} \mathrm{~N}^{15} \mathrm{~N}\right)$ from the measured isotope distribution in $\mathrm{N}_{2}$ from the overlying water and the slurry. The denitrification rates were then calculated from the areal production rates according to:

$$
\begin{aligned}
& D_{15}=p^{14} \mathrm{~N}^{15} \mathrm{~N}+2 \times p^{15} \mathrm{~N}^{15} \mathrm{~N} \\
& D_{14}=D_{15} \times \frac{p^{14} \mathrm{~N}^{15} \mathrm{~N}}{2 \times p^{15} \mathrm{~N}^{15} \mathrm{~N}} \\
& D^{101}=D_{15}+D_{14}
\end{aligned}
$$

where $D_{15}$ and $D_{14}$ are the denitrification rates of ${ }^{15} \mathrm{NO}_{3}{ }^{-}$ and ${ }^{14} \mathrm{NO}_{3}{ }^{-}$, respectively, and $D^{\text {tol }}$ is the total rate of denitrification in the ${ }^{15} \mathrm{NO}_{3}{ }^{-}$amended core system.

The rate of denitrification based on added plus ambient nitrate from the overlying water $\left(D_{w}{ }^{\text {tot }}\right)$, the rate of denitrification coupled to nitrification $\left(D_{n}\right)$ and the denitrification of ambient nitrate from the water $\left(D_{w}\right)$ were then calculated as:

$$
\begin{aligned}
D_{\mathrm{w}}{ }^{\mathrm{tot}} & =D_{15} / f \\
D_{\mathrm{n}} & =D^{\mathrm{tot}}-D_{\mathrm{w}}{ }^{\mathrm{tot}} \\
D_{\mathrm{w}} & =\frac{D_{\mathrm{w}}^{\mathrm{tot}}}{\left[\mathrm{NO}_{3}^{-}\right]_{i}} \times\left[\mathrm{NO}_{3}^{-}\right]_{a}
\end{aligned}
$$

where $f$ is the fraction of ${ }^{15} \mathrm{~N}$ labelled $\mathrm{NO}_{3}{ }^{-}$in the overlying water, $\left[\mathrm{NO}_{3}{ }^{-}\right]$, is the nitrate concentration in the water phase after ${ }^{15} \mathrm{NO}_{3}{ }^{-}$addition prior to capping the cores and $\left[\mathrm{NO}_{3}{ }^{-}\right]_{a}$ is the ambient $\mathrm{NO}_{3}{ }^{-}$concentration 
(measured in the tank water before preincubation). Total unamended denitrification is the sum of $D_{w}$ and $D_{\text {n. }}$

The rate of nitrification not coupled to denitritication, but released as $\mathrm{NO}_{3}$ to the overlying water $\left(N_{\mathrm{w}}\right)$, was measured from the fractional changes in ${ }^{15} \mathrm{~N}$ labelling of $\mathrm{NO}_{3}$ in the overlying water during incubation, $\Delta f$ (adapted from Nishio et al. 1983):

$$
N_{\mathrm{w}}=\frac{\left[\mathrm{NO}_{3}{ }^{-}\right] \times \Delta f}{0.00366-f} \times \frac{h}{\Delta t}
$$

where $\left[\mathrm{NO}_{3}{ }^{-}\right]$is the mean concentration during incubation, $h$ is the water phase height and $\Delta t$ the incubation time. Total nitrification is the sum of $D_{n}$ and $N_{w}$.

\section{RESULTS}

\section{Seasonal study}

The ambient $\mathrm{NO}_{3}^{-}$concentration increased from near zero in summer and fall 1993 to $65-70 \mu \mathrm{M}$ in late winter/early spring 1994. Ambient $\mathrm{NH}_{4}{ }^{+}$concentrations varied from near zero found in summer to about $10 \mu \mathrm{M}$ in winter (Fig. 2A). The dark $\mathrm{O}_{2}$ uptake in sum-

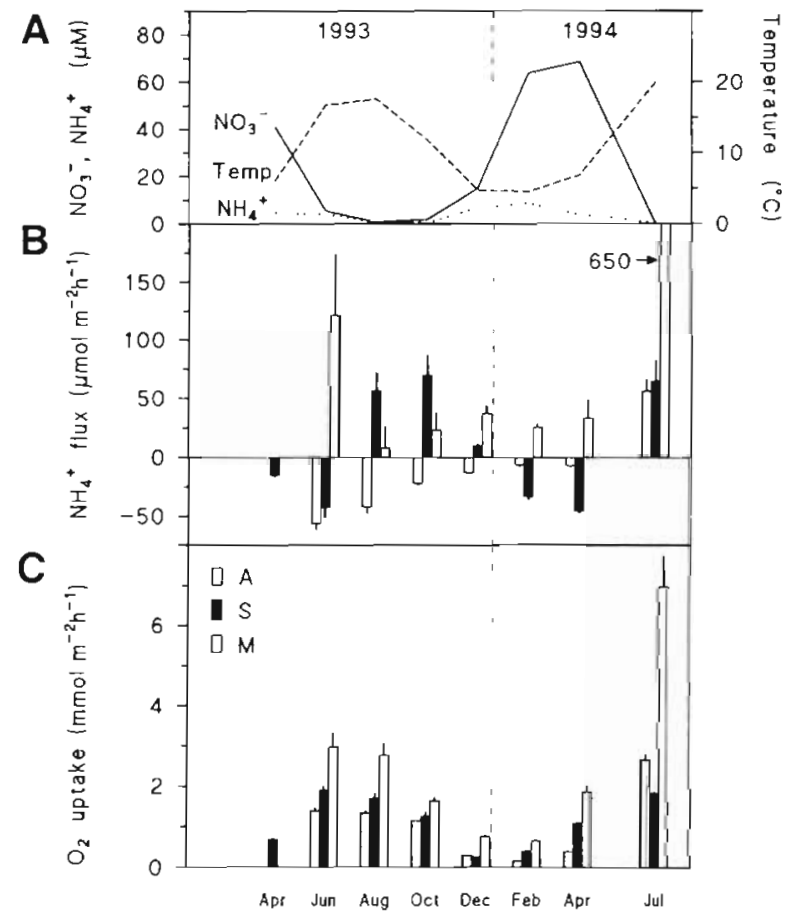

Fig. 2. Seasonal variation in (A) ambient $\mathrm{NO}_{3}{ }^{-}\left(+\mathrm{NO}_{2}{ }^{-}\right)$and $\mathrm{NH}_{4}{ }^{+}$concentration in the water phase and incubation temperature, (B) dark $\mathrm{NH}_{4}{ }^{+}$flux (positive values indicate release) and $(\mathrm{C})$ dark $\mathrm{O}_{2}$ uptake. Standard error of the mean is indicated. Only Stn $\mathrm{S}$ was included in April 1993

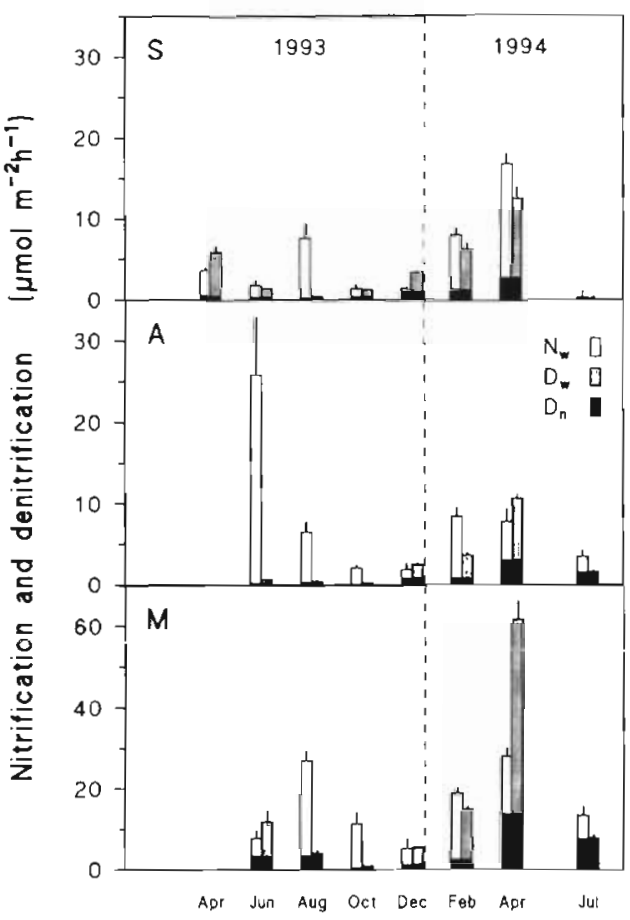

Fig. 3. Seasonal variation of dark nitrification and denitrification at the 3 stations. Nitrification is the sum of $D_{n}$ and $N_{w}$ whereas denitrification is the sum of $D_{n}$ and $D_{w}$. Standard error of the mean is indicated. Only $\mathrm{S}$ was included in April 1993. Note the different scales on the vertical axes

mer was 2 to 2.5 and 3 to $6.5 \mathrm{mmol} \mathrm{m} \mathrm{m}^{-2} \mathrm{~h}^{-1}$ on the sandy and muddy sediments, respectively, and decreased to below $1 \mathrm{mmol} \mathrm{m}^{-2} \mathrm{~h}^{-1}$ in winter (Fig. 2C). At Stn $\mathrm{A}$, the $\mathrm{NH}_{4}{ }^{+}$flux (Fig. 2B) was always directed into the sediment (from -6 to $-56 \mu \mathrm{mol} \mathrm{m} \mathrm{m}^{-2} \mathrm{~h}^{-1}$ ) with lowest uptake in winter and spring, except for July 1994 when $\mathrm{NH}_{4}{ }^{+}$ was released significantly $\left(56 \mu \mathrm{mol} \mathrm{m}^{-2} \mathrm{~h}^{-1}\right)$. At $\mathrm{M}$, $\mathrm{NH}_{4}{ }^{+}$was always released from the sediment. Highest rates were observed in summer $\left(120\right.$ and $650 \mu \mathrm{mol} \mathrm{m} \mathrm{m}^{-2}$ $\mathrm{h}^{-1}$ ), whereas the range was 8 to $37 \mu \mathrm{mol} \mathrm{m} \mathrm{m}^{-2} \mathrm{~h}^{-1}$ the rest of the year. At $\mathrm{S}, \mathrm{NH}_{4}{ }^{+}$was released from late summer to early winter (10 to $65 \mu \mathrm{mol} \mathrm{m} \mathrm{m}^{-2} \mathrm{~h}^{-1}$ ), but taken up during the rest of the year (from -16 to $-46 \mu \mathrm{mol} \mathrm{m}^{-2} \mathrm{~h}^{-1}$ ). For all study periods and stations the addition of $30 \mu \mathrm{M}^{15} \mathrm{NO}_{3}^{-}$(or higher) in the denitrification incubations did not influence the $\mathrm{NH}_{4}{ }^{+}$flux as judged by comparison to parallel unamended incubations (E. Kristensen et al. unpubl.).

The overall pattern of denitrification generally showed low rates from summer to early winter for all stations ( 0 to $8 \mu \mathrm{mol} \mathrm{m}{ }^{-2} \mathrm{~h}^{-1}$ ) when $\mathrm{NO}_{3}^{-}$concentration in the overlying water was below $2 \mu \mathrm{M}$ (Fig. 3). The increasing rates in late winter and spring (maximum around $11 \mu \mathrm{mol} \mathrm{m} \mathrm{m}^{-2} \mathrm{~h}^{-1}$ in sandy sediment and up to $62 \mu \mathrm{mol} \mathrm{m}^{-2} \mathrm{~h}^{-1}$ at $\mathrm{M}$ in April) corresponded to the 
increasing $\mathrm{NO}_{3}{ }^{-}$concentration in the water phase (maximum of 65 to $70 \mu \mathrm{M}$ in April). Denitrification of $\mathrm{NO}_{3}{ }^{-}$from the overlying water $\left(D_{\mathrm{w}}\right)$ accounted for 60 to $90 \%$ of the total denitrification during most of the year, but during summer, when $\mathrm{NO}_{3}{ }^{-}$was depleted, the contribution of $D_{\mathrm{w}}$ was only a few percent. The annual mean dark denitrification rate at $S, A$ and $M$ (from June 1993 to April 1994) was 4.2, 3.0 and $17 \mu \mathrm{mol} \mathrm{m}{ }^{-2}$ $\mathrm{h}^{-1}$, respectively, of which $D_{\mathrm{w}}$ accounted for 75,69 and $74 \%$.

Nitrification rates ranged from 1 to $17 \mu \mathrm{mol} \mathrm{m} \mathrm{m}^{-2} \mathrm{~h}^{-1}$ at $\mathrm{S}$. The rates at $\mathrm{A}$ were in the same range except for 1 high value of $26 \mu \mathrm{mol} \mathrm{m} \mathrm{m}^{-2} \mathrm{~h}^{-1}$ in June 1993. At the muddy Stn $M$ nitrification rates were somewhat higher, ranging between 5 and $28 \mu \mathrm{mol} \mathrm{m}{ }^{-2} \mathrm{~h}^{-1}$. The nitrification rates were generally lowest in early winter at all 3 stations. At $\mathrm{S}$ and $\mathrm{M}_{1}$ nitrification showed 2 maxima, one in spring and one in late summer. At A, however, a maximum in nitrification was evident in June. The highest rates of coupled nitrification-denitrification were found in spring (April 1994). The fraction of total nitrification which was coupled to denitrification $\left[D_{\mathrm{n}} /\left(N_{\mathrm{w}}+D_{\mathrm{n}}\right)\right]$ was with few exceptions below $50 \%$. The lowest values ranging from 1 to $5 \%$ were found at $\mathrm{A}$ in June, $\mathrm{S}$ in August and $\mathrm{M}$ in October. The annual mean rate of dark nitrification at $\mathrm{S}, \mathrm{A}$ and $\mathrm{M}$ (June 1993 to April 1994) was 6.1, 8.7 and $16 \mu \mathrm{mol} \mathrm{m}^{-2}$ $\mathrm{h}^{-1}$, respectively, of which 17,11 and $27 \%$ was coupled to denitrification.

\section{Test incubations \\ Influence of ${ }^{15} \mathrm{NO}_{3}{ }^{-}$additions}

The rates of $\mathrm{O}_{2}$ uptake, DIN exchange and denitrification in cores with variable ${ }^{15} \mathrm{NO}_{3}{ }^{-}$additions showed consistent results irrespective of station and season (Fig. 4). The presence of the cockle Cerastoderma edule at Stn $\mathrm{M}$ influenced fluxes and process rates considerably and forced us to separate cores in this specific experiment into those with and those without this actively filtrating animal. The $\mathrm{O}_{2}$ uptake was independent of the $\mathrm{NO}_{3}{ }^{-}$concentration whereas the $\mathrm{NO}_{3}{ }^{-}$ uptake (measured net $\mathrm{NO}_{3}{ }^{-}$uptake plus $N_{\mathrm{w}}$ ) increased linearly with $\mathrm{NO}_{3}{ }^{-}$concentration within the range measured. The $\mathrm{NH}_{4}{ }^{+}$release was generally independent of the $\mathrm{NO}_{3}{ }^{-}$concentration, but positively correlated with the $\mathrm{O}_{2}$ uptake in the $\mathrm{M}$ sediment $\left(\mathrm{r}^{2}>0.64\right.$; not shown). An $\mathrm{NH}_{4}{ }^{+}$uptake was generally observed in April except in muddy cores containing $C$. edule.

Proportionality between the water phase $\mathrm{NO}_{3}{ }^{-}$concentration and the corresponding denitrification of $\mathrm{NO}_{3}{ }^{-}$from the water phase $\left(D_{\mathrm{w}}{ }^{\mathrm{lot}}\right)$ is indicated by regression lines in Fig. 4. Higher $D_{w}{ }^{\text {tot }}$ than expected
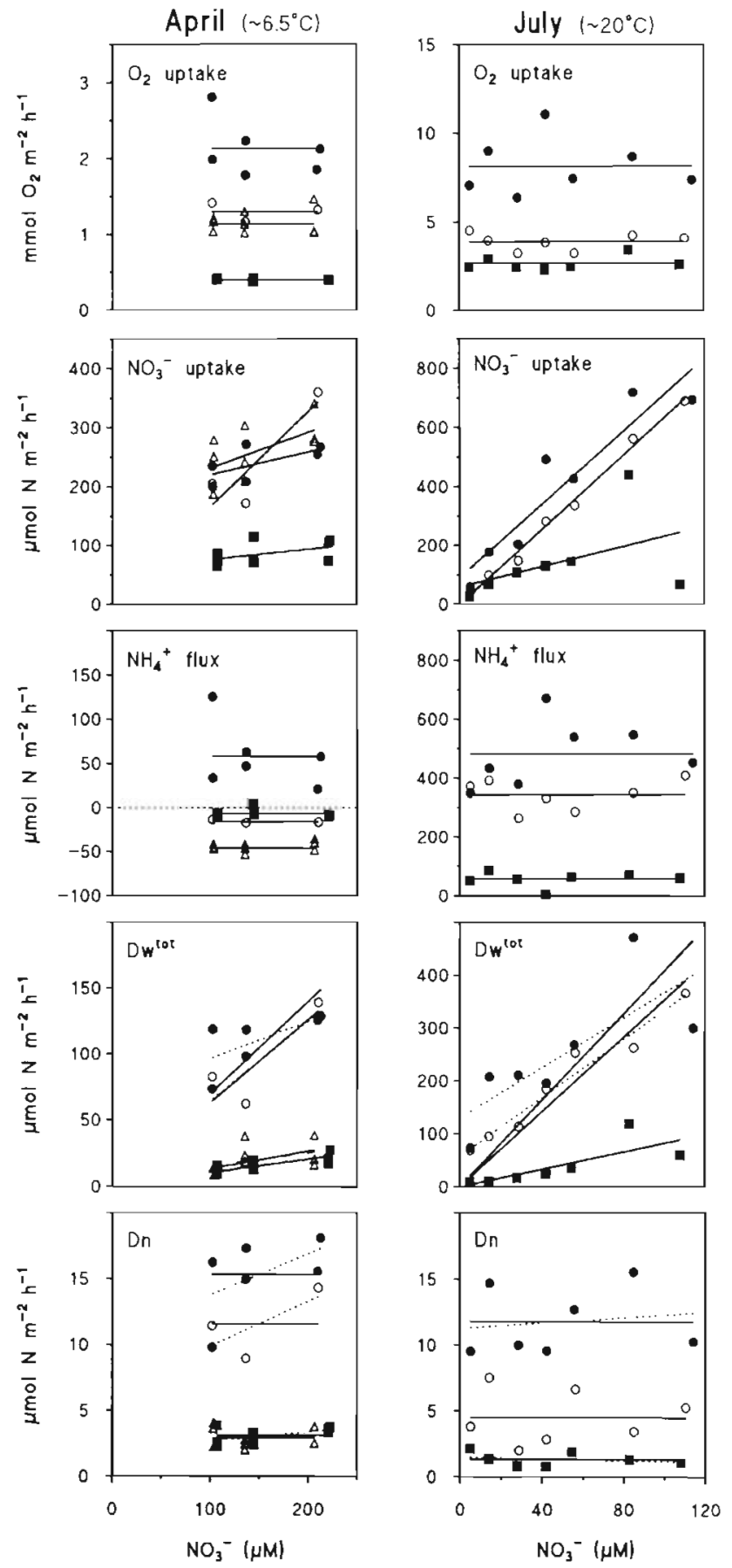

Fig. 4. Effect of variable ${ }^{15} \mathrm{~N}$-nitrate additions on measured dark fluxes of $\mathrm{O}_{2}$ and $\mathrm{NH}_{4}{ }^{+}, \mathrm{NO}_{3}^{-}\left(+\mathrm{NO}_{2}{ }^{-}\right)$uptake and estimated $D_{\mathrm{w}}{ }^{\text {tot }}$ and $D_{\mathrm{n}}$. The test was carried out in a situation of low $(<0.1 \mu \mathrm{M}$, July 1994) and high ambient nitrate $(65$ to $71 \mu \mathrm{M}$, April 1994). (@) $\mathrm{M}^{+} ;(O) \mathrm{M}^{-} ;(\Delta) \mathrm{S}_{i}(\mathbf{D}) \mathrm{A}_{i}+$ and - indicate cores with and without Cerastoderma edule. For $\mathrm{O}_{2}$ and $\mathrm{NH}_{4}{ }^{+}$fluxes the mean values are indicated as horizontal lines and for $\mathrm{NO}_{3}{ }^{-}$uptake the free linear regression lines are shown. For $D_{\mathrm{w}}{ }^{\text {tot }}$ the lines for linear regression forced through zero as well as the free linear regression lines (dotted) are given. For $D_{\mathrm{n}}$ the mean values and the free linear regression lines (dotted) are given. Positive $\mathrm{NH}_{4}{ }^{+}$fluxes indicate release 
were found for the lowest $\mathrm{NO}_{3}{ }^{-}$additions in the $\mathrm{M}$ sediment. Using free linear regression, significant deviation of the intercept from zero ( $t$-test, $\alpha=0.05$; Zar 1984) was only found in the $M$ sediment without Cerastoderma edule in July. Omitting the 2 lowest concentrations from the regression, the intercept was not significantly different from zero. The rate of coupled nitrification-denitrification $\left(D_{\mathrm{n}}\right)$ was not significantly affected by the added ${ }^{15} \mathrm{NO}_{3}{ }^{-}$regardless of ambient $\mathrm{NO}_{3}{ }^{-}$, i.e. significant deviation of the slope from zero was not detected.

\section{Microalgal interference}

The addition of $\mathrm{NO}_{3}{ }^{-}$in the AA incubations (Table 1 ; Incubation 2) did not affect $\mathrm{NH}_{4}{ }^{+}$and $\mathrm{O}_{2}$ fluxes compared to the initial unamended incubation (1). In the ${ }^{15} \mathrm{NO}_{3}{ }^{-}$incubations $(2 \& 3)$ the $\mathrm{NO}_{3}{ }^{-}$concentration was approximately doubled compared to the unamended situation (69 to $76 \mu \mathrm{M}$ ) causing almost a doubling of $\mathrm{NO}_{3}{ }^{-}$uptake in the cores with no $\mathrm{NH}_{4}{ }^{+}$added. Addition of $\mathrm{NH}_{4}{ }^{+}$on the other hand reduced this increased $\mathrm{NO}_{3}{ }^{-}$uptake by 20 to $43 \%$. In the ${ }^{15} \mathrm{NO}_{3}{ }^{-}$incubation without $\mathrm{NH}_{4}{ }^{+}$approximately $14 \%$ of the $\mathrm{NO}_{3}{ }^{-}$uptake was denitrified in S and A sediment compared to $35 \%$ for $\mathrm{M}$ sediment. When $\mathrm{NH}_{4}{ }^{+}$was added, denitrification of $\mathrm{NO}_{3}{ }^{-}$from the water phase was increased by 41 to $44 \%$ in the $\mathrm{S}$ and $\mathrm{A}$ sediment and reduced by $13 \%$ in the $\mathrm{M}$ sediment. About one third of the $\mathrm{NO}_{3}{ }^{-}$taken up was then denitrified in all sediment types. At the 2 sandy sediments, $\mathrm{NH}_{4}{ }^{+}$additions increased the coupled nitrification-denitrification significantly, whereas at $M$ the effect was insignificant ( $t$-test, $\alpha=0.05$ ). For all 3 sediments, the effect of $\mathrm{NH}_{4}{ }^{+}$addition on $N_{\mathrm{w}}$ (the part of nitrification not coupled to denitrification but released as $\mathrm{NO}_{3}{ }^{-}$to the overlying water) was smaller than $(\mathrm{S}, \mathrm{A})$ or similar to $(\mathrm{M})$ the effect on coupled nitrification, $D_{\mathrm{n}}$.

The constant-dark (CD) treatment (Table 2; Incubatioñ 3) showed no significantint impact on $\mathrm{O}_{2}$ uptake compared to the standard $2 \mathrm{~h}$ dark preincubated cores with $\mathrm{NO}_{3}{ }^{-}$(Incubation 2), but $\mathrm{NH}_{4}{ }^{+}$release was increased and at Stn $\mathrm{S}, \mathrm{NO}_{3}{ }^{-}$uptake was decreased. In $\mathrm{S}$ and $\mathrm{Mx}$ sediments, 8 and $22 \%$, respectively, of the $\mathrm{NO}_{3}{ }^{-}$uptake was denitrified in the standard ${ }^{15} \mathrm{NO}_{3}{ }^{-}$ incubation, compared to 27 and $57 \%$ when the dark preincubation time was prolonged to $48 \mathrm{~h}$. Both parts of the nitrification $\left(D_{\mathrm{n}}\right.$ and $\left.N_{\mathrm{w}}\right)$ were increased severalfold after the $48 \mathrm{~h}$ dark preincubation period.

Table 1. Effect of adding surplus $(500 \mu \mathrm{M}\} \mathrm{NH}_{4}{ }^{+}$on $\mathrm{O}_{2}$ and DIN (dissolved inorganic nitrogen) uptake, nitrification and denitrification in April 94 (AA incubations). Results for the first incubation (1) are taken from Kristensen et al. (unpubl.), and the una-

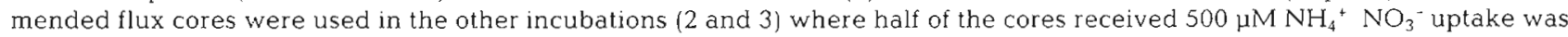
determined by adding $N_{\mathrm{w}}$ to the measured net $\mathrm{NO}_{3}{ }^{-}$uptake ( $N_{\mathrm{w}}$ from Incubation 2 was used to correct the measured net $\mathrm{NO}_{3}$ uptake in Incubation 1). Stimulation of $D_{\mathrm{W}^{\prime}}{ }^{\text {tot }}$ is normalized to the same nitrate concentration. Negative sign for $\mathrm{NH}_{4}{ }^{+}$flux denotes uptake. Standard error of the mean is indicated

\begin{tabular}{|c|c|c|c|c|c|c|c|}
\hline $\begin{array}{l}\text { Station } \\
\text { Incubation }\end{array}$ & $\begin{array}{l}\mathrm{NO}_{3}^{-} \\
(\mu M)\end{array}$ & $\begin{array}{c}\mathrm{O}_{2} \text { uptake } \\
\left(\mathrm{mmol} \mathrm{m} \mathbf{m}^{-2} \mathrm{~h}^{-1}\right)\end{array}$ & $\mathrm{NH}_{4}{ }^{+}$flux & $\mathrm{NO}_{3}^{-}$uptake & $\begin{array}{c}D_{w}{ }^{10 \mathrm{ol}} \\
\left.\text { ol } \mathrm{m}^{-2} \mathrm{~h}^{-1}\right)\end{array}$ & $D_{\mathrm{n}}$ & $N_{\mathrm{w}}$ \\
\hline \multicolumn{8}{|l|}{$\mathrm{s}$} \\
\hline (1) Unamended & 71 & $1.06 \pm 0.08$ & $-27 \pm 2$ & $176 \pm 25$ & & & \\
\hline (2) ${ }^{15} \mathrm{NO}_{3}^{-}$ & 132 & $1.21 \pm 0.04$ & $-34 \pm 2$ & $265 \pm 20$ & $37 \pm 6$ & $3.2 \pm 0.4$ & $10 \pm 1$ \\
\hline (3) ${ }^{15} \mathrm{NO}_{3}{ }^{-}+\mathrm{NH}_{4}{ }^{+}$ & 134 & $1.27 \pm 0.16$ & -958 & $152 \pm 43$ & $52 \pm 6$ & $6.1 \pm 0.7$ & $11 \pm 2$ \\
\hline \multicolumn{2}{|c|}{ Stimulation: } & & & $-43 \%^{c}$ & $+41 \%^{\circ}$ & $+91 \%$ & $+3 \%$ \\
\hline \multicolumn{8}{|l|}{ A } \\
\hline (1) Unamended & 76 & $0.55 \pm 0.04$ & $-18 \pm 5$ & $66 \pm 7$ & & & \\
\hline (2) ${ }^{15} \mathrm{NO}_{3}$ & 128 & $0.66 \pm 0.09$ & $-20 \pm 1$ & $107 \pm 20$ & $15 \pm 2$ & $1.7 \pm 0.1$ & $2.9 \pm 0.7$ \\
\hline \multirow{2}{*}{ (3) $\begin{aligned} &{ }^{15} \mathrm{NO}_{3}{ }^{-}+\mathrm{NH}_{4}{ }^{+} \\
& \text {Stimulat }\end{aligned}$} & 127 & $0.64 \pm 0.03$ & -458 & $63 \pm 9$ & $21 \pm 0$ & $3.7 \pm 0.2$ & $4.9 \pm 0.4$ \\
\hline & & & & $-41 \%$ & $+44 \%$ & $+120 \%$ & $+67 \%$ \\
\hline \multicolumn{8}{|l|}{$M$} \\
\hline (1) Unamended & 69 & $2.2 \pm 0.2$ & $36 \pm 20$ & $197 \pm 44$ & & & \\
\hline (2) ${ }^{15} \mathrm{NO}_{3}^{-}$ & 134 & $2.4 \pm 0.4$ & $49 \pm 23$ & $294 \pm 44$ & $102 \pm 19$ & $13 \pm 2$ & $20 \pm 10$ \\
\hline (3) ${ }^{15} \mathrm{NO}_{3}{ }^{-}+\mathrm{NH}_{4}{ }^{+}$ & 132 & $2.1 \pm 0.3$ & -1815 & $236 \pm 13$ & $88 \pm 2$ & $16 \pm 2$ & $27 \pm 2$ \\
\hline \multicolumn{3}{|c|}{ Stimulation: } & & $-20 \%$ & $-13 \%$ & $+25 \%$ & $+32 \%$ \\
\hline \multicolumn{8}{|c|}{$187 \%$ if compared to the seasonal study } \\
\hline
\end{tabular}


Table 2. Effect of preincubation time in darkness on $\mathrm{O}_{2}$ and DIN uptake, nitrification and denitrification in June 1993 (CD incubations). Results for the first incubation (1) are taken from Kristensen et al. (unpubl.). A standard $2 \mathrm{~h}$ dark preincubation was used in the second incubation, whereas in the third incubation the cores were preincubated for $48 \mathrm{~h}$ in darkness before ${ }^{15} \mathrm{NO}_{3}{ }^{-}$addition. Corrected $\mathrm{NO}_{3}{ }^{-}$uptake, stimulation of $D_{\mathrm{w}}{ }^{(0)}, \mathrm{NH}_{4}{ }^{+}$flux sign and standard error as in Table 1

\begin{tabular}{|c|c|c|c|c|c|c|c|}
\hline $\begin{array}{l}\text { Station } \\
\text { Incubation }\end{array}$ & $\begin{array}{l}\mathrm{NO}_{3}^{-} \\
(\mu \mathrm{M})\end{array}$ & $\begin{array}{c}\mathrm{O}_{2} \text { uptake } \\
\left(\mathrm{mmol} \mathrm{m}^{-2} \mathrm{~h}^{-1}\right)\end{array}$ & $\mathrm{NH}_{4}^{+}$flux & $\mathrm{NO}_{3}$ uptake & $\begin{array}{c}D_{w^{10}} \\
\left.\text { ol } \mathrm{m}^{-2} \mathrm{~h}^{-1}\right)\end{array}$ & $D_{n}$ & $N_{\mathrm{w}}$ \\
\hline \multicolumn{8}{|l|}{ S } \\
\hline (1) Unamended & 6.3 & $2.5 \pm 0.3$ & $33 \pm 11$ & $40 \pm 4$ & & & \\
\hline (2) $2 \mathrm{~h}^{15} \mathrm{NO}_{3}^{-}$ & 41 & $1.9 \pm 0.1$ & $-43 \pm 9$ & $147 \pm 14$ & $12 \pm 2$ & $0.34 \pm 0.06$ & $1.4 \pm 0.7$ \\
\hline (2) $48 \mathrm{~h}^{15} \mathrm{NO}_{3}$ & 39 & $1.6 \pm 0.2$ & $152 \pm 29$ & $70 \pm 8$ & $19 \pm 2$ & $0.85 \pm 0.19$ & $5.6 \pm 0.5$ \\
\hline \multicolumn{2}{|l|}{ Stimulation: } & & & $-52 \%$ & $+66 \%^{b}$ & $+150 \%$ & $+307 \%$ \\
\hline \multicolumn{8}{|l|}{$\mathrm{Mx}$} \\
\hline (1) Unamended & 5.3 & $2.3 \pm 0.1$ & $261 \pm 15$ & $14 \pm 7$ & & & \\
\hline (2) $2 \mathrm{~h}^{15} \mathrm{NO}_{3}^{-}$ & 43 & $2.3 \pm 0.1$ & $250 \pm 22$ & $192 \pm 11$ & $42 \pm 6$ & $2.0 \pm 0.2$ & $10 \pm 2$ \\
\hline (2) $48 \mathrm{~h}^{15} \mathrm{NO}_{3}^{-}$ & 46 & $2.4 \pm 0.1$ & $440 \pm 16$ & $178 \pm 3$ & $101 \pm 13$ & $11 \pm 3$ & $59 \pm 26$ \\
\hline \multicolumn{2}{|l|}{ Stimulation: } & & & $-7 \%$ & $+125 \%$ & $+453 \% \mathrm{~b}$ & $+492 \%{ }^{b}$ \\
\hline \multicolumn{8}{|c|}{ Significant difference ( $t$-test, $\alpha=0.05$ ) } \\
\hline
\end{tabular}

\section{DISCUSSION}

\section{Reliability of the methods}

Three basic assumptions have to be satisfied when the ${ }^{15} \mathrm{~N}$ pairing technique is used for ambient denitrification measurements (Nielsen 1992): (1) the added nitrate should not interfere with the denitrification of ambient water phase nitrate $\left(D_{\mathrm{w}}\right)$, implying that denitrification of nitrate from the water phase should be proportional to the nitrate concentration; (2) the rate of coupled nitrification-denitrification $\left(D_{n}\right)$ should be unaffected by the ${ }^{15} \mathrm{~N}$-nitrate concentration indicating an even distribution of the nitrate isotopes in the denitrification zone; and (3) the measured rates should be unaffected by the incubation time.

In the sandy $\mathrm{S}$ and $\mathrm{A}$ sediments the first and second assumptions were fulfilled at ${ }^{15} \mathrm{~N}$-nitrate concentrations from 5 to $120 \mu \mathrm{M}$ (Fig. 4). In the muddy $\mathrm{M}$ sediment the second assumption was satisfied but the lowest ${ }^{15} \mathrm{~N}$-nitrate additions tended to give higher $D_{w}$ rates. This could be caused by the pronounced heterogeneity of this muddy sediment. Other studies using the same technique on sandy or silty sediments found no such effect on $D_{w}$ (Pelegrí et al. 1994, Rysgaard et al. 1995, Nielsen \& Glud 1996). Since a minimum of $30 \mu \mathrm{M}{ }^{15} \mathrm{~N}$-nitrate additions were used in our seasonal incubations we therefore assumed a proportionality between $D_{w}{ }^{\text {tot }}$ and the nitrate concentration.

The third assumption is critical as the present isotope pairing technique requires a relatively long time for the ${ }^{15} \mathrm{~N}$-nitrate gradient to stabilize within the sediment. The same stabilization time (15 $\mathrm{min}$ ) was used during all study periods and this time was probably somewhat too long in summer and too short in winter. However, much longer incubation times were used in order to make the effect of the stabilization time small. In most of the seasonal incubations presented here, different durations of incubation were used and the effect of time proved insignificant ( $t$-test, $\alpha=0.05$ ).

The use of the isotope dilution technique in shallow areas requires that the measurement of $N_{w}$, the part of nitrification where the produced nitrate is released to the water phase, is independent of microphytobenthic activity. As the calculation of $N_{w}$ is based on the dilution of the water phase ${ }^{15} \mathrm{~N}$-nitrate during incubation, algal assimilation of the ${ }^{14} \mathrm{~N}$-nitrate produced by nitrification before entering the water phase could create a serious underestimation of $N_{\mathrm{w}}$. A decrease in algal DIN assimilation is therefore expected to stimulate the measured $N_{\mathrm{w}}$ more than $D_{\mathrm{n}}$. The ammonium addition (AA) and the constant- dark (CD) experiments showed that microphytobenthic nitrate uptake only interfered to a limited extent with the measurement of $N_{\mathrm{w}}$. despite an effect of the microalgae on the overall nitrification rate. We only observed an effect in the sandy $\mathrm{S}$ sediment in June which may have been coincidental. The low interference from the microalgae on the measurement of $N_{w}$ was somewhat surprising, since more than two thirds of the nitrate uptake in the dark denitrification incubation was assimilated by the algae (Tables $1 \& 2$ ). The AA and CD treatments might have altered the depth distribution of nitrification in the oxic zone as has been shown in experiments with ammonium addition to dark incubated homogenized sediment (Jensen et al. 1993), but this should actually 
increase the ratio $N_{w} /\left(N_{w}+D_{n}\right)$. A plausible explanation could be that the microphytobenthic activity was restricted to a very narrow surface zone, where the concentration of nitrate diffusing from the water column was much higher than the concentration of nitrate diffusing from a nitrification zone located deeper in the oxic zone (Jensen et al. 1993, 1994).

Previous ${ }^{15} \mathrm{~N}$-nitrate isotope dilution studies using continuous flow systems with estuarine diatom-inhabited sediments in day-night cycles have provided contradictory results. Thus, Risgaard-Petersen et al. (1993) observed a stabilization of the isotope dilution within few hours after light was turned off indicating a subsequent stable $N_{w}$ measurement; whereas Rysgaard et al. (1993) in a similar sediment found that algal assimildion of nitrate continued for about $25 \mathrm{~h}$ after light was turned off and more than $10 \mathrm{~h}$ was required for $N_{\mathrm{w}}$ to stabilize. Since we have used the same preincubation procedure in all our investigations and found no significant changes of $N_{w}$ in our time course incubations, we believe that the present measurement of dark nitrification not coupled to denitrification is not seriously affected by microphytobenthic activity.

\section{Seasonal variations of denitrification}

The dominating source of nitrate for dark denitrification was from the water phase at all stations and for most of the year. $D_{w}$ followed largely the water phase nitrate concentration (Figs. 2 \& 3) with highest rates in April 1994. The coupled rate $\left(D_{n}\right)$ dominated only during summer when the overlying water was almost nitrate depleted. The highest rates of coupled denitrification were, nevertheless, found in spring. Similar results have previously been found in other coastal sediments (Nielsen et al. 1994, Rysgaard et al. 1995). Spring maxima of sediment denitrification at relatively low, but increasing, temperatures in near-coastal areas (Jørgensen \& Sørensen 1985, Jensen et al. 1988) have been explained by high water phase nitrate concentrations combined with progressively lower oxygen penetration depth (i.e. small diffusion distance for nitrate) due to increasing $\mathrm{O}_{2}$ consumption (Jensen et al. 1990).

Assuming that nitrate is denitrified in a narrow zone just underneath the oxic zone and that microphytobenthic assimilation of nitrate or other nitrate-consuming processes do not interfere with the flux of nitrate to the denitrification zone, Fick's first law can be used to calculate the denitrification of nitrate from the water phase:

$$
D_{\mathrm{w}}=D_{\mathrm{NO}_{3}} \times \phi^{\mathrm{m}} \times\left[\mathrm{NO}_{3}^{-}\right] / Z_{\mathrm{O}_{2}}
$$

where $D_{\mathrm{NO}_{3}}$ is the diffusion coefficient of nitrate in seawater $(30 \%)$ corrected for temperature $(T): D_{\mathrm{NO}_{3}}=$
$(9.36+0.33 \times T) \times 10^{-6} \mathrm{~cm}^{2} \mathrm{~s}^{-1} ; \phi$ is the mean porosity in the oxygen penetration zone $Z_{\mathrm{O}_{2}}$ and $m=2$ or 3 depending on the porosity being below or above 0.7 ( $\mathrm{Li}$ \& Gregory 1974, Ullnnan \& Aller 1982, Christcnsen et al. 1990). The oxygen penetration depths in the dark varied seasonally from 5 to $20 \mathrm{~mm}$ at $\mathrm{S}$, and from 0.4 to $4 \mathrm{~mm}$ at $\mathrm{M}$ (Bruns et al. 1995); oxygen penetration depths were not measured at Stn A. This diffusionbased approach has been intensively used and verified in previous denitrification studies (Christensen et al. 1990, Nielsen et al. 1990b, Jensen et al. 1994, Risgaard-Petersen et al. 1994, Rysgaard et al. 1994). It should be noted, however, that the oxygen penetration depths used here were not measured during the same incubations or in the same cores as the denitrification rates and differences in stirring conditions and general core variability could be of importance. Another problem in the present study is the low depth resolution of the porosity measurement in the upper sediment layer ( $3 \mathrm{~mm}$ ), since diffusivity may change considerably in the upper few millimeters of the sediment (Jensen et al. 1994). Despite these considerations, the calculated values were generally close to the corresponding measured values of $D_{\mathrm{w}}$ (Fig. 5). Large deviations were only found at $S$ in April 1994, and at M in June 1993 probably due to microalgal interference (see Tables 1 \& 2). There were, however, no indications that assimilation by the benthic microalgae severely affected the transport of nitrate to the denitrification zone at other times, even though $D_{\mathrm{w}}$ only accounted for $13 \%$ (range 1 to $66 \%$ ) of the total $\mathrm{NO}_{3}$ uptake (i.e. minus measured $\mathrm{NO}_{3}{ }^{-}$flux from Fig. 6 plus $N_{\mathrm{w}}$ from Fig. 3) with highest

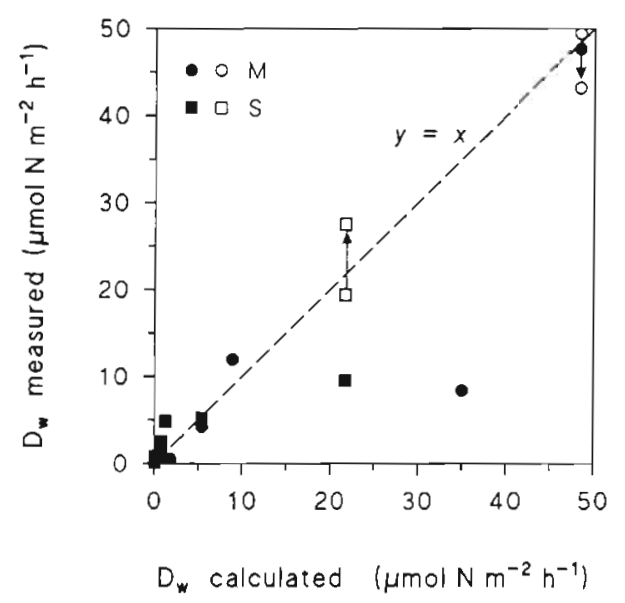

Fig. 5. Measured versus calculated $D_{w}$. Calculated $D_{w}$ is based on Fick's first law using measured water phase $\mathrm{NO}_{3}{ }^{-}$ concentration and dark $\mathrm{O}_{2}$ penetration depths (see text). Open symbols: data from the AA experiment (Table 1.; Incubations 2 and 3), where arrows indicate the effect of the ammonium addition (the results are normalized to the ambient nitrate concentration) 


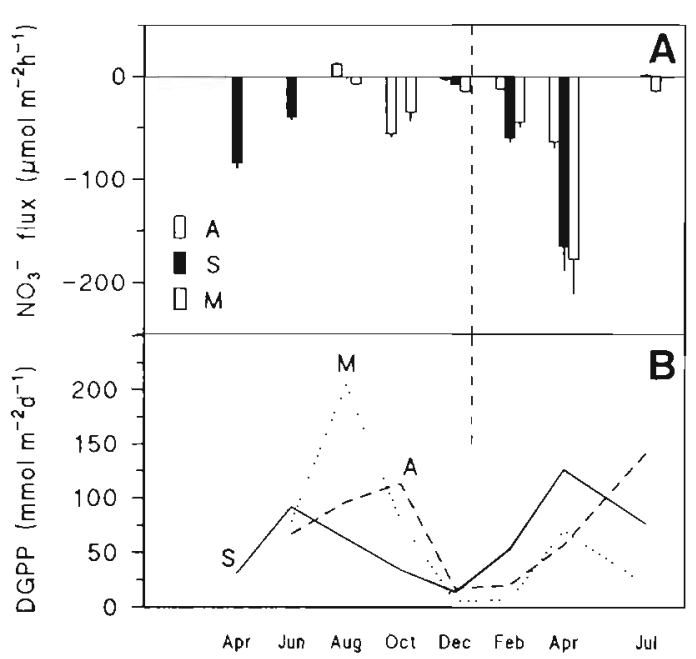

Fig. 6. Seasonal variation in (A) dark unamended $\mathrm{NO}_{3}^{-}$ $\left(+\mathrm{NO}_{2}{ }^{-}\right)$flux (negative values denotes uptake) and $(\mathrm{B})$ daily gross primary production (DGPP is $\mathrm{O}_{2}$ production in light $+\mathrm{O}_{2}$ uptake in dark corrected for length of day). Results are obtained from Kristensen et al. (unpubl.); these incubations were conducted in parallel with the ${ }^{15} \mathrm{~N}$ incubations. In April and June 1993, $\mathrm{NO}_{3}^{-}$flux was only measured at Stn S; $\mathrm{NO}_{3}{ }^{-}$flux was not measured at $\mathrm{S}$ in October 1993 and at $\mathrm{A}$ in July 1994

values in winter and in the middle of summer. Microsensor investigations and model calculations have previously shown that competition between $\mathrm{NO}_{3}{ }^{-}$assimilation in a narrow surface zone and denitrification in deeper anoxic zones could be negligible (Nielsen et al. $1990 \mathrm{~b})$.

The annual mean dark denitrification rate of water phase $\mathrm{NO}_{3}^{-}\left(D_{w^{\prime}}\right)$ increased in the sequence $\mathrm{A}, \mathrm{S}, \mathrm{M}$. This was probably due to smaller diffusional distances for water phase $\mathrm{NO}_{3}{ }^{-}$to the denitrification zone with increasing oxygen uptake (Fig. 2). Similar results were obtained from biofilms (Nielsen et al. 1990a) and marine sediments (Jensen et al. 1988, Caffrey et al. 1993, Sloth et al. 1995) with different organic loadings. The difference in mean dark denitrification at the 3 stations is probably a result of organic matter content and reactivity and thus differences in mineralization rate.

\section{Seasonal variations of nitrification}

Dark nitrification was low in the early winter in all sediments probably due to low temperature and low mineralization (i.e. low $\mathrm{NH}_{4}{ }^{+}$production). Low nitrification during winter has frequently been observed in seasonal investigations of coastal sediments (MacFarlane \& Herbert 1984, Seitzinger et al. 1984), but the opposite pattern has also been reported (Hansen et al.
1981). In all 3 sediments the nitrification increased in February, probably as a response to increasing $\mathrm{NH}_{4}{ }^{+}$ availability, although the $\mathrm{NH}_{4}{ }^{+}$concentration in the water column only increased slightly (Fig. 2A).

A spring maximum in nitrification rate was detected in April at $\mathrm{M}$ and $\mathrm{S}$ whereas nitrification was repressed in the middle of summer. Low nitrification rates during warm summer months have been explained by a combination of low oxygen availability, $\mathrm{H}_{2} \mathrm{~S}$ inhibition and competition for $\mathrm{NH}_{4}{ }^{+}$(Hansen et al. 1981, Jenkins \& Kemp 1984, Seitzinger et al. 1984, Henriksen \& Kemp 1988, Kemp et al. 1990, Joye \& Hollibaugh 1995). In the present study, conditions of low oxygen availability and presence of $\mathrm{H}_{2} \mathrm{~S}$ could prevail and inhibit nitrification since intense sulfate reduction was observed throughout the summer (maximum $2.3 \mathrm{mmol} \mathrm{m}^{-2} \mathrm{~h}^{-1}$ at Stn M; Kristensen et al. 1996) with peak rates close to the sediment surface. The sulfate reduction was still high in August when a late summer maximum in nitrification rate was evident at $M$ and $S$, but it was observed that maxima in nitrification at these 2 stations generally occurred at the time of maxima in daily gross primary production, DGPP (Fig. 6). Although no correlation was evident between dark nitrification and dark oxygen penetration, the microalgal oxygen production during daylight hours may have had a prolonged oxidizing effect during the night. The correspondence between DGPP and nitrification indicates that competition for $\mathrm{NH}_{4}^{+}$was of minor importance especially on $\mathrm{M}$, where ammonium was always released from the sediment (Fig. 2). The $\mathrm{NH}_{4}{ }^{+}$addition experiment (AA) also indicated that microalgal assimilation of $\mathrm{NH}_{4}{ }^{+}$could be less inhibitory to nitrification in the muddy $M$ sediment than in the sandy $\mathrm{S}$ sediment. However, an inhibition of nitrification by the microalgae was indicated in the $\mathrm{CD}$ incubation in the sandy $\mathrm{S}$ sediments during early summer (June 1993, July 1994) when the correspondence between DGPP and nitrification was absent.

A different pattern of seasonal control of nitrification may be present at $\operatorname{Stn} A$. Thus, in this sediment no relationship was evident between nitrification and DGPP (Fig. 6). Instead the highest nitrification was found in summer (June 1993) when DGPP was relatively low. Ammonium was nearly always taken up by this sediment (Fig. 2) and the effect of $\mathrm{NH}_{4}{ }^{+}$addition (AA experiment) indicated that the inorganic nitrogen availability was more limited at $\mathrm{A}$ than at $\mathrm{S}$, which diminished the role of $\mathrm{O}_{2}$ availability. Nitrification at Stn A was probably controlled by competition for ammonium with the benthic microalgae combined with a positive influence of temperature on both mineralizing and nitrifying bacteria. Similar seasonal trends have been found by Nixon et al. (1976), Seitzinger et al. (1984) and MacFarlane \& Herbert (1984). It should be noted that the rates of nitrification presented 
here may be underestimated, especially at Stn A, due to the absence of deep burrowing Arenicola marina in our cores. Previous results from Königshafen (Hüttel 1990) have indicated that bioturbation by these animals has a stimulating effect on nitrification deep in the sediment.

Coupling of nitrification and denitrification $\left[D_{n} /\left(N_{w}\right.\right.$ $\left.+D_{n}\right)$ ] was generally low, especially during late summer or autumn in all sediment types (Fig. 3). A low coupling in autumn has been observed from investigations in deeper North Sea sediments (Lohse et al. 1993). Nitrification during this period may have occurred at the very top of the oxic zone, fed by $\mathrm{NH}_{4}{ }^{+}$from mineralization and animal excretion in the aerobic zone.

The 2 different patterns of seasonal control of nitrification in the 3 sediment tynes was probably caused by increasing mineralization in the sequence $A, S, M$ (Fig. 2). This is in accordance with the higher organic contents of the muddy sediment compared to the 2 sandy sediments, although a significant difference in bulk organic content between the 2 sandy sediments was not evident. Similar conclusions were drawn by Lohse et al. (1993) from studies of nitrification in sediments of the southeastern North Sea. The annual mean dark nitrification rate was higher in the muddy $M$ than in the sandy sediments. Increased nitrification under moderate organic loading have been predicted from models (Blackburn 1990, Blackburn \& Blackburn 1993) and experimentally verified in marine sediment systems (Caffrey et al. 1993, Sloth et al. 1995). Another controlling factor could be the dependence of nitrifying bacteria on surface area (Henriksen \& Kemp 1988). It seems plausible that the higher mean dark nitrification rate at the muddy sediment compared to the 2 sandy sediments was an effect of a higher content of organic rich fine particles combined with higher mineralization rates.

Acknowledgements. We thank S. Andreassen and B. F. Jacobsen for technical assistance and R. Bruns, M. Hollinder and the staff at the Wattenmeerstation Sylt for their cooperation and hospitality. We also thank S. P. Pelegrí, N. RisgaardPetersen and L. P. Nielsen for their assistance with the GCMS measurements and R. P. Cox for support with the MI-MS measurements and for drawing the map. The project was supported by the German Ministry of Research (BMBF) in relation to project SWAP (Sylt Wattenmeer Austausch Prozesse; subproject 2.1/3.4b, contract no. 03F $0006 \mathrm{D} 0$ ) and by grants from Direktor Ib Henriksens Fond.

\section{LITERATURE CITED}

Armstrong FAJ, Stearns CR, Strickland JDH (1967) The measurement of upwelling and subsequent biological processes by means of the Technicon Autoanalyzer and associated equipment. Deep Sea Res 14:381-389
Blackburn TH (1990) Denitrification model for marine sediment. In: Revsbech NP, Sorensen J (eds) Denitrification in soil and sediment. FEMS Symposium No. 56, Plenum Press, New York, p 323-338

Blackburn TH, Blackburn ND (1.993) Coupling of cycles and global significance of sediment diagenesis. Mar Geol 113 . $101-110$

Bower CE, Holm-Hansen T (1980) A salicylate-hypochlorite method for determining ammonia in seawater. Can J Fish Aquat Sci 37:794-798

Bruns R, Hollinde M, Meyer-Reil LA (1995) Untersuchungen zu mikrobiellen Nährstoffumsetzungen. Abschlussbericht, Sylter Wattenmeer Austausch Prozesse, Teilprojekt 2.1/ 3.4 b, Christian-Albrechts-Universität, Kiel

Caffrey JM, Sloth NP, Kaspar HF, Blackburn TH (1993) Effect of organic loading on nitrification and denitrification in a marine sediment microcosm. FEMS Microbiol Ecol 12: $159-167$

Chatarpaul L, Robinson JB, Kaushik NK (1980) Effects of tubificid wumis on deritiffication and nitrification in stream sediment. Can J Fish Aquat Sci 37:656-663

Christensen PB, Nielsen LP, Sorensen J, Revsbech NP (1990) Denitrification in nitrate-rich streams: diurnal and seasonal variation related to benthic oxygen metabolism. Limnol Oceanogr 35:640-651

Hansen JI, Henriksen K, Blackburn TH (1981) Seasonal distribution of nitrifying bacteria and rates of nitrification in coastal marine sediments. Microb Ecol 7:297-304

Henriksen K, Kemp WM (1988) Nitrification in estuarine and coastal marine sediments. In: Blackburn TH, Sørensen J (eds) Nitrogen cycling in coastal marine environments. SCOPE 33. John Wiley and Sons, Chichester, p 205-249

Højberg O, Johansen HS, Sørensen J (1994) Determination of ${ }^{15} \mathrm{~N}$ abundance in nanogram pools of $\mathrm{NO}_{3}{ }^{-}$and $\mathrm{NO}_{2}{ }^{-}$by denitrification bioassay and mass spectrometry. Appl Environ Microbiol 60:2467-2472

Hüttel M (1990) Influence of the lugworm Arenicola marma on porewater nutrient profiles of sand flat sediments. Mar Ecol Prog Ser 62:241-248

Jenkins MC, Kemp WM (1984) The coupling of nitrification and denitrification in two estuarine sediments. Limnol Oceanogr 29:609-619

Jensen KM, Jensen MH. Cox RP (1996) Membrane inlet mass spectrometric analysis of $\mathrm{N}$-isotope labelling for aquatic denitrification studies. FEMS Microbiol Ecol 20:101-1.09

Jensen K, Revsbech NP, Nielsen LP (1993) Microscale distribution of nitrification activity in sediment determined with a shielded microsensor for nitrate. Appl Environ Microbiol 59:3287-3296

Jensen K. Sloth NP, Risgaard-Petersen N, Rysgaard S, Revsbech NP (1994) Estimation of nitrification and denitrification from microprofiles of oxygen and nitrate in model sediment systems. Appl Environ Microbiol 60:2094-2100

Jensen MH, Andersen TK, Sørensen J (1988) Denitrification in coastal bay sediment: regional and seasonal variation in Aarhus Bight, Denmark. Mar Ecol Prog Ser 48:155-162

Jensen $\mathrm{MH}$, Lomstein E, Serensen $\mathrm{J}$ (1990) Benthic $\mathrm{NH}_{4}{ }^{+}$and $\mathrm{NO}_{3}{ }^{-}$flux following sedimentation of a spring phytoplankton bloom in Aarhus Bight, Denmark. Mar Ecol Prog Ser $61: 87-96$

Jørgensen BB, Sørensen J (1985) Seasonal cycles of $\mathrm{O}_{2}, \mathrm{NO}_{3}{ }^{-}$ and $\mathrm{SO}_{4}{ }^{2-}$ reduction in estuarine sediments: the significance of an $\mathrm{NO}_{3}$ reduction maximum in spring. Mar Ecol Prog Ser 24:65-74

Joye SB, Hollibaugh JT (1995) Influence of sulfide inhibition of nitrification on nitrogen regeneration in sediments. Science 270:623-625 
Kemp WM, Sampou P, Caffrey J, Mayer M, Henriksen K Boynton WR (1990) Ammonium recycling versus denitrification in Chesapeake Bay sediments. Limnol Oceanogr 35:1545-1563

Koike 1, Hattori A (1978) Simultaneous determinations of nitrification and nitrate reduction in coastal sediments by a ${ }^{15} \mathrm{~N}$ dilution technique. Appl Environ Microbiol 35 $853-857$

Kristensen E, Andersen Fø (1987) Determination of organic carbon in marine sediments: a comparison of two CHNanalyzer methods. J Exp Mar Biol Ecol 109:15-23

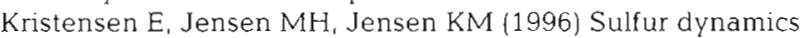
in sediments of Königshafen. In: Reise $\mathrm{K}$ et al. (eds) SWAP - Sylter Wattenmeer Austauschprozesse, projekt synthese. Boysen, Tönning, p 193-213

Li YH, Gregory S (1974) Diffusion of ions in sea water and in deep-sea sediments. Geochim Cosmochim Acta 38: $703-714$

Lohse L, Kloosterhuis HT, van Raaphorst W, Helder W (1996) Denitrification rates as measured by the isotope pairing method and by the acetylene inhibition technique in continental shelf sediments of the North Sea. Mar Ecol Prog Ser 132:169-179

Lohse L, Malschaert JFP, Slomp CP, Helder W, van Raaphorst W (1993) Nitrogen cycling in North Sea sediments: interactions of denitrification and nitnfication in offshore and coastal areas. Mar Ecol Prog Ser 101:283-296

MacFarlane GT, Herbert RA (1984) Dissimilatory nitrate reduction and nitrification in estuarine sediments. J Gen Microbiol 130:2301-2308

Nielsen LP (1992) Denitrification in sediment determinated from nitrogen isotope pairing. FEMS Microbiol Ecol 86: $357-362$

Nielsen LP, Christensen PB, Revsbech NP, Sørensen J (1990a) Denitrification and oxygen respiration in biofilms studied with a microsensor for nitrous oxide and oxygen. Microb Ecol 19:63-72

Nielsen LP, Christensen PB, Revsbech NP, Sorensen J (1990b) Denitrification and photosynthesis in stream sediment studied with microsensor and whole-core techniques. Limnol Oceanogr 35:1135-1144

Nielsen LP, Christensen PB, Rysgaard S (1994) Denitrifikation i fjorde og kystnære farvande. Havforskning fra Miljøstyrelsen nr 50. Miljostyrelsen, København

Nielsen LP, Glud RN (1996) Denitrification in a coastal sediment measured in situ by the nitrogen isotope parring technique applied to a benthic flux chamber. Mar Ecol Prog Ser 137:181-186

Nishio T, Koike I, Hattori A (1983) Estimates of denitrification

Responsible Subject Editor: T. H. Blackburn, Aarhus, Denmark and nitrification in coastal and estuarine sediments. Appl Environ Microbiol 45:444-450

Nixon SW, Oviatt CA, Hale SS (1976) Nitrogen regeneration and metabolism of coastal marine bottom communities. In: Anderson J, Macfadyan A (eds) The role of terrestrial and aquatic organisms in decomposition processes. Blackwell, Oxford, p 269-283

Pelegrí SP. Blackburn TH (1995) Effects of Tubifex tubifex (Oligochaeta: Tubificidae) on $\mathrm{N}$-mineralization in freshwater sediments, measured with ${ }^{15} \mathrm{~N}$ isotopes. Aquat Microb Ecol 9:289-294

Pelegri SP, Nielsen LP, Blackburn TH (1994) Denitrification in estuarine sediment stimulated by the irrigation activity of the amphipod Corophium volutator. Mar Ecol Prog Ser 105:285-290

Reise K (1985) Tidal flat ecology. Ecological Studies 54, Springer-Verlag, Berlin

Risgaard-Petersen N, Rysgaard S, Nielsen LP, Revsbech NP (1994) Diurnal variation of denitrification and nitrification in sediments colonized by benthic microphytes. Limnol Oceanogr 39:573-579

Risgaard-Petersen N, Rysgaard S, Revsbech NP (1993) A sensitive assay for determination of ${ }^{14} \mathrm{~N} /{ }^{15} \mathrm{~N}$ isotope distribution in $\mathrm{NO}_{3}{ }^{-} \mathrm{J}$ Microbiol Methods 17:155-164

Rysgaard S, Christensen PB, Nielsen LP (1995) Seasonal variation in nitrification and denitrification in estuarine sediment colonized by benthic microalgae and bioturbating infauna. Mar Ecol Prog Ser 126:111-121

Rysgaard S, Risgaard-Petersen N, Nielsen LP, Revsbech NP (1993) Nitrification and denitrification in lake and estuarine sediments measured by the ${ }^{15} \mathrm{~N}$ dilution technique and isotope pairing. Appl Environ Microbiol 59:2093-2098

Rysgaard S, Risgaard-Petersen $N$, Sloth NP, Jensen $K$, Nielsen LP (1994) Oxygen regulation of nitrification and denitrification in sediments. Limnol Oceanogr 39 : $1643-1652$

Seitzinger SP, Nixon SW, Pilson MEQ (1984) Denitrification and nitrous oxide production in a coastal marine ecosystem. Limnol Oceanogr 29:73-83

Sloth NP, Blackburn TH, Hansen LS, Risgaard-Petersen N, Lomstein BAa (1995) Nitrogen cycling in sediments with different organic loading. Mar Ecol Prog Ser 116:163-170

Solorzano L (1969) Determination of ammonia in natural waters by the phenol-hypochlorite method. Limnol Oceanogr 14:799-801

Ullman WJ, Aller RC (1982) Diffusion coefficients in nearshore marine sediments. Limnol Oceanogr 27:552-556

Zar JH (1984) Biostatistical analysis. Prentice-Hall International Inc, London

Manuscript first received: May 29, 1996

Revised version accepted: August 20, 1996 